\title{
G20 Governance of Digitalization ${ }^{1}$
}

\author{
J.J. Kirton, B. Warren
}

John J. Kirton - Professor, Co-director of BRICS Research Group, Director of G8 Research Group, Co-director of G20 Research Group, University of Toronto; 1 Devonshire Place, Room 209 N, Toronto, M5S 3K7 Ontario, Canada; E-mail: john.kirton@utoronto.ca

Brittaney Warren - Director of Compliance of G7 Research Group and G20 Research Group; 1 Devonshire Place, Room 308N, Toronto, M5S 3K7, Ontario, Canada; E-mail: b.warren@mail.utoronto.ca

\begin{abstract}
This study systematically assesses the Group of 20 (G20) summit's performance on digitalization across the key dimensions and suggests what has caused its particular pattern of performance thus far [Kirton, 2013]. It argues that the G20 summit's digitalization governance has been increasingly successful. Its digitalization agenda steadily expanded since the beginning, with a major surge in 2016-17. G20 summits first addressed digitalization in response to the American-turned-global financial crisis of 2008. Then, G20 leaders acknowledged e-commerce as an important tool to manage the crisis. They then gradually expanded their agenda to finally focus on inequality, a root cause of antiglobalization. They thus moved from a crisis-response to a crisis-prevention approach. This spread and spike is seen in the G20's direction-setting, decision-making and institutional development of global governance, but not in its delivery of its decisions. This overall performance was driven partly by the shocking surge in populism bred by inequality in the UK and U.S. in 2015 and 2016, by the failure of the established multilateral organizations in response, by the global predominance and equalizing capabilities of 620 members in specialized digital capabilities and their convergence on the economic growth through openness that digitalization brought. Yet this performance flowed primarily from the hosting of economically reforming China in 2016 and export-oriented Germany in 2017, whose politically secure leaders sought to shape digitalization for the benefit of all in response to the rise of populism and protectionism in the UK and the United States. ${ }^{2}$
\end{abstract}

Key words: digitalization; digital economy; dimensions of performance; G20; inequality; antiglobalization; causes of performance.

For citation: Kirton J.J., Warren B. (2018) G20 Governance of Digitalization. International Organisations Research Journal, vol. 13, no 2, pp. 16-41 (in Russian and English). DOI: 10.17323/1996-7845-2018-02-02.

\section{Introduction}

The digital revolution is quickly arriving in full force. It brings many challenges, but also many benefits and opportunities for all. Indeed, digitalization does contain significant risks. In a report prepared for the German presidency of the Group of 20 (G20), the Organisation for Economic Co-operation and Development (OECD) stated that "digital technologies may be disruptive, with far-reaching effects on productivity, employment and well-being... these tech-

${ }^{1}$ The editorial board received the article in December 2017.

${ }^{2}$ We are grateful for the research assistance of Alecs Dragus and other members of the G20 Research Group. 
nologies are also likely to displace workers doing specific tasks and may further increase gaps in access and use, resulting in new digital divides and greater inequality" [2017]. Yet with half of the world's household wealth concentrated in the hands of the top $1 \%$ of the population [Global Wealth Report, 2017], inequality is already intense, driving populist and antiglobalization sentiments in the United States, the United Kingdom and elsewhere. Moreover, high rates of youth unemployment and persistent gender disparities in the work place in many countries, including the undervaluing of the caring economy, have not been driven by automation but by neglect and long-standing gender-based biases.

Digitalization in a globalized world also brings many benefits. It has the potential to save lives, to help meet the climate change challenge and to create jobs. The OECD report acknowledges this, saying "technologies, smart applications and other innovations in the digital economy can improve services and help address policy challenges in a wide range of areas, including health, agriculture, public governance, tax, transport, education, and the environment, among others" [OECD, 2017]. Self-driving vehicles have the potential to prevent traffic accidents which cost millions of lives and to reduce energy consumption by up to $90 \%$. Job loss will be sector specific and may come in fewer than 5\% of occupations [Manyika et al., 2017]. Moreover, jobs will be created in the technology industry and, in a twist of fate, in the traditionally undervalued female-dominated fields requiring high empathy, communication and human interaction [Patel, 2017]. In most cases, humans and robots will work together to produce better lives for many.

Whether the opportunities and benefits or the costs and risks prevail depends importantly on the decisions governments make both at home and at their global summits, particularly those of the systemically significant G20.

\section{The Scholarly Debate}

How well and why the G20 summit has governed digitalization is a question that has attracted little attention thus far. Most of the existing accounts are highly prescriptive, proposing what the G20 should do rather than assessing what it has done and why.

The first school sees great positive potential, if the G20 acts the right way. Sarah Mariani and Martin Dionne [2017] argue that artificial intelligence (AI) can be utilized by the G20 to realize its core mission of making globalization work for all, as it "offers a way to better coordinate a diverse, interconnected world." They note that AI was introduced at the Hangzhou summit in 2016 as a disrupter of production, but should be presented as a builder of sustainable communities locally and globally. They recommend that the G20 deliberate more on how AI can improve global governance by making more decisions to promote AI research funding, entrepreneurship and community building, and by encouraging global connectivity. Barin Carin [2017] calls for action to secure the financial sector. Krish Chetty et al. [2017] recommend a G20 advisory body to spur digital skills' development. And Julie Maupin [2017] asks the G20 to decisively harness blockchain technology.

The second school sees a promising spike in performance at the G20's Hamburg summit held on 7-8 July 2017. Dennis Snower [2017, p. 5] notes that this summit sought to address the challenges of "technological change, as well as a sense of disempowerment in the presence of automation and digitalization." Snower sees digitalization as one of the summit's "three major achievements," noting the leaders' declaration to "strive to ensure that all our citizens are digitally connected by 2025 and especially welcome infrastructure development in low-income countries in that regard" and to "promote digital literacy and digital skills in all forms of education and life-long learning” [Snower, 2017, p. 3]. 
The third school, representing one systematic review of G20 summit performance, points to the G20's poor performance in this field. John Kirton and Brittaney Warren [2017] assess the impact of 89 recommendations, including 20 on digitalization, that experts assembled in the Think Twenty (T20) process prepared for the G20 Hamburg summit. The 20 digitalization recommendations covered four areas: digital safeguards with eight recommendations, employment and education policies for the digital age with six, harnessing blockchain technology with four and safeguarding the financial system from cyberattacks with two. The T20's emphasis was thus on reducing risks rather than seizing opportunities. Only five, or 25\%, of the 20 digitalization recommendations were realized among the 533 commitments G20 leaders made at Hamburg. All five were only partially rather than fully realized. Three of these were on employment and education policies for the digital age and two were on safeguarding the financial system from cyberattacks. Similarly, digitalization was not noted among the several achievements that made Hamburg a summit of significant success [Kirton, 2017].

\section{The Thesis}

To advance this debate, this study systematically assesses G20 summit performance on digitalization across several key dimensions and offers suggestions for understanding the pattern of performance thus far [Kirton, 2013].

It argues that G20 summit governance of digitalization has been a growing success. Its digitalization agenda has steadily expanded since it emerged, with a major surge in 2016-2017. G20 summits first addressed digitalization in response to the American-turned-global financial crisis of 2008 as leaders acknowledged e-commerce as an important tool to manage the crisis. They gradually expanded the agenda to focus on inequality, a root cause of antiglobalization, moving from a crisis-response to a crisis-prevention approach. This spread and spike is seen in the G20's direction-setting, decision-making and institutional development of global governance, but not in the delivery of its decisions. This overall performance was driven partly by the shocking surge in populism bred by inequality in the UK and U.S. in 2015 and 2016, by the failure of the established multilateral organizations in response, by the global predominance and equalizing capabilities of G20 members in specialized digital capabilities and their convergence on the economic growth through openness that digitalization brought. Yet this performance flowed primarily from the hosting of economically reforming China in 2016 and export-oriented Germany in 2017, whose politically secure leaders sought to shape digitalization for the benefit of all in response to the rise of populism and protectionism in the U.S. and the UK.

\section{Dimensions of Performance}

G20 summit performance on digitalization across most major dimensions shows a small, expanding performance since the start, with a surge in 2016 and 2017 [Kirton, 2013] (see Appen$\operatorname{dix} A)$.

\section{Deliberation}

Public deliberation is the first dimension of summit performance, measured by the treatment of the digital economy and other aspects of digitalization in collective communiqués issued at summits by the leaders. Examination of this dimension shows that G20 deliberation of digitalization was initially focused on the global financial crisis. Then, with a few gaps, its scope 
steadily expanded with a major spike in 2016-17 (see Appendix B). This expansion reflected the growing importance of digitalization in daily life, culminating in an emphasis on digital inequality. By the 2017 Hamburg summit a strong gender-digital connection had been made, while the climate-digital connection had not yet been established. Overall, the approach has shifted; initially framed as a threat to the economy and jobs, digitalization is now seen as opportunity with potential benefits.

The digital economy first appeared on the G20's agenda at its first summit in Washington, DC on 14-15 November 2008. In response to the global financial crisis, G20 leaders "insisted that market participants support exchange traded or electronic trading platforms for [credit default swaps] contracts" [G20, 2008]. Electronic trading, or e-trading, was absent at the 2009 London summit, but reappeared at the Pittsburg summit in September 2009. Digital trade remained on the agenda at other summits with the exception of the meetings in Seoul (2010) and Brisbane (2014), during which there was no deliberation on the digital economy at all. At the 2016 Hangzhou summit the terms "e-commerce" and "digital trade" replaced the term "electronic trading."

At the 2010 Toronto summit the agenda expanded from e-commerce to digital financial inclusion, with consideration given to creating a "clear regulatory framework for electronically stored value" [G20, 2010]. The shift from financial stability to globalization for all as the underlying benefit was thus made at an early stage. References to electronically stored value then stopped, with digital currencies and blockchain technology not yet making it onto the leaders' agenda. The closest connection was the reference at Cannes in 2011 to the European Union's ambitions to create a digital single market. Similarly, digital financial inclusion fell off the agenda at Cannes. But it returned in full force at the 2016 Hangzhou summit with an endorsement of the G20 High-Level Principles for Digital Financial Inclusion.

The phrase "digital economy" itself was first used at the 2013 St. Petersburg summit. The subject was addressed in 760 words in the leaders' official documents (a tiny $3 \%$ of the total) and arose in $27 \%$ of the documents issued. Leaders presented digitalization as a threat to international taxation and noted the increasing international trade in intangibles, with the OECD identified as the body best placed to respond.

After an absence in 2014, the digital economy reappeared at the 2015 Antalya summit. It was addressed in 299 words making up $33 \%$ of the documents released. The tone shifted to a balance between threats and benefits, with the leaders declaring: "We are living in an age of Internet economy that brings both opportunities and challenges to global growth" [G20, 2015]. The agenda also continued to expand with both digital security and the importance of digital inclusiveness beyond the financial sphere recognized in a commitment to bridge the digital divide.

Significant gains were made at the Hangzhou summit in 2016. Attention to the subject spiked to 3,042 words making up $19 \%$ of the communiqué and other official documents. Leaders mainstreamed the subject across all of their documents. In a largely positive portrayal, they emphasized the potential of digitalization to boost economic growth. They also authoritatively defined this new issue area in their G20 Blueprint on Innovative Growth, stating: "The digital economy refers to a broad range of economic activities that includes using digitalized information and knowledge as the key factor of production, modern information networks as the important activity space, and the effective use of Information and Communication Technology (ICT) as an important driver for efficiency-enhancing and economic structural optimizations" [G20, 2016].

To "unleash the potential of the digital economy," the leaders established the G20 Digital Economy Development and Cooperation Initiative. All of the issues addressed at previous summits (with the exception of digital stores of value) remained on the agenda and several new 
ones were added. Leaders identified the opportunities of the New Industrial Revolution (NIR), the Internet of Things (IoT), Big Data, cloud computing, AI, robotics, additive manufacturing, new materials, augmented reality, nanotechnology and biotechnology. They also emphasized digital inclusiveness beyond financial inclusiveness by committing to "bridge the digital divide." For the first time they spoke about digital skills, including for entrepreneurs.

At Hamburg on 7-8 July 2017, as measured by 5,029 words on the subject making up $14 \%$ of the communiqué and other official documents, the leaders increased their attention and further expanded the agenda to "harness" the "digital transformation." New issues of security, consumer protection and intellectual property rights emerged, with the G20 endorsing the G20 Roadmap for Digitalization. On security, the G20 invited their finance ministers to work with fintech (financial technology) firms to fight terrorist financing. Issues related to modernizing the agriculture industry by providing digital services and deploying digital infrastructure were introduced and became priorities for the G20 Argentinian presidency in 2018.

The major expansion at Hamburg, however, was the forging of a strong digital-gender connection. The G20 recognized the need to "improve digital skills and employment perspectives for girls and women in emerging and developing countries." As such, they welcomed the G20 Digital Economy Ministerial Declaration "which intends to promote action to help bridge the gender digital divide" and recognized the "multiple vulnerabilities" women and girls face that act as barriers to their full participation in the digital economy, including lack of digital literacy skills. The G20 further recognized that digital technologies can "serve as a tool to strengthen women's and girls' rights" and "to reduce economic and social disparities." Finally, the G20 also recognized the importance of "enhanc[ing] women's and girls' digital privacy and security" [G20, 2017a].

\section{Direction-Setting}

The second performance dimension is principled and normative direction-setting, measured by communiqué affirmations of the G20's distinctive foundational missions to promote financial stability and make globalization work for all, and also of the companion Group of Seven's (G7) distinctive foundational mission to promote open democracy and human rights. The G20 strongly emphasized making the digitalization component of globalization work for the benefit of all, a principle affirmed through 109 references (see Appendix C). The principle of digital governance for financial stability was affirmed 48 times, that of open democracy 23 times and that of human rights just four. Thus, the emphasis on equitable global distribution and digitalization for development dominated, while the principle of digitalization for democracy took a distant third place.

\section{Decision-Making}

On the third dimension, decision-making through the leaders' precise, future-oriented and politically obligatory public commitments, performance had long been limited and sporadic, but surged in 2016 and 2017 (see Appendix D and D-1). The 10 summits produced only 58 commitments on the digital economy, or a mere $2 \%$ of the 2,398 they produced overall, and only 30 related to digitalization.

Digital economy commitments first arose at the start in 2008 with one made in that year. None were made at the four summits held in 2009 or 2010. Digital economy commitments returned from 2011 to 2013 with one commitment made at each summit, only to disappear 
again from 2014 to 2015. Then, in 2016, the number of digital economy commitments soared to 29 , and slid only a little in 2017 to 25 .

Over the first eight summits, the issues dealt with shifted unsteadily from financial regulation in 2008 to macroeconomics in 2011, then to financial regulation again in 2012 and development in 2013. In 2016, 29 commitments covered seven issue areas: ICT with 22, financial regulation with two and trade, G20 governance, international cooperation, development and labour-employment with one each. In 2017 the 25 commitments again covered seven issue areas but were more evenly spread - gender was covered by 10, economy and trade by four each, development by three, ICT by two and labour-employment and food-agriculture by one each. Despite the more even distribution, however, Hamburg was a digital-gender summit above all.

Apart from the digital economy, the G20 made 30 commitments on issues related to digitalization. One of these was made at the 2015 Antalya summit (on bridging the digital divide) and the rest were made at the 2017 Hamburg summit. Here the commitments were on ensuring that all citizens are digitally connected by 2025 , with explicit recognition of the alignment with Sustainable Development Goal 9, promoting digital skills, education and literacy, data protection, digital agriculture, online terrorist recruiting and gender issues such as developing digitalization policies that reduce stereotypes related to gender and ICT and cyber violence against girls.

\section{Delivery}

On the fourth dimension, delivery of the decisions through compliance with the commitments prior to the next summit, the very slim available evidence suggests that performance was very low. On the closest issue area, ICT - the only commitment assessed for compliance out of the 49 made from 2008 to 2015 - had an average compliance of +0.10 or $55 \%$ (see Appendix D and E). This is the lowest of the 20 issues areas assessed. It is well below the average of +0.40 or $70 \%$ across all $\mathrm{G} 20$ issue areas.

Four digital economy commitments and one related commitment have been assessed for compliance. Average compliance with these five commitments was very low at $50 \%$. The lowest compliance, at $15 \%$, was for the commitment to unleash the digital economy by promoting policies to support microenterprises, defined as businesses with no more than 10 employees. Here all G20 countries scored -1 for noncompliance, with only Argentina (the 2018 G20 host), Canada (the 2018 G7 host) and Australia in full compliance. The second lowest, the commitment to unleash the potential of the digital economy through entrepreneurship, had 53\% compliance. The commitment on reducing inequalities through bridging the digital divide had a compliance rate of $55 \%$, followed by the commitment to unleash the digital economy through e-commerce cooperation at $58 \%$. Finally, the highest scoring commitment was the broadest of the five. Here the G20 committed to unleash the digital economy by promoting digital transformation, scoring $68 \%$. On digital transformation, Japan was the clear leader meeting $100 \%$ of the criteria required for full compliance with its plan to create a "super smart" Society 5.0.

By member, across all five digitalization commitments, Canada led at $100 \%$. It was followed by Argentina, Australia and the European Union at $80 \%$ each. Next came the UK and Korea at $70 \%$, followed by France at $60 \%$. In the middle, at $50 \%$ each, came China, Germany, Brazil and Saudi Arabia. At the bottom came India and Russia at $40 \%$ each, followed by Japan at $30 \%$. Despite Japan's ambitious Society 5.0 vision, it failed to comply with the commitments to bridge the digital divide and to support entrepreneurs and microenterprises. The U.S., South Africa and Mexico also all had $30 \%$ compliance. Turkey and Italy had $20 \%$ compliance, leaving Indonesia in last place at $10 \%$. 
Overall, the members comprising the $\mathrm{G} 7$ had $45 \%$ compliance; only the full compliance of Canada, the 2018 G7 host, kept the average score near the positive range. Among the BRICS grouping of Brazil, Russia, India, China and South Africa, China and Brazil led with 50\%. The overall average for BRICS members was lower than the $\mathrm{G} 7$ average at $42 \%$.

\section{Development of Global Governance}

On the fifth dimension, the institutional development of global governance inside and outside the G20, performance was strong (see Appendix F). There was a total of 152 references to such institutions, with an almost perfect split between references to institutions inside the G20 (73) and those to bodies outside (79). This suggests the G20 intended to govern digital globalization itself, in addition to using older institutions to do so.

The first institution referenced in the context of digitalization was the Financial Stability Board (FSB) at the 2009 Pittsburgh summit. No institutional references arose at the 2010 summits in Toronto and Seoul. At the Cannes summit in 2011 the first references to an institution outside of the G20 were made, with seven. No inside institutions were referenced at Cannes. At Los Cabos in 2012 there were two references, one to the G20 itself and another to the FSB. St. Petersburg in 2013 had seven inside references and six outside ones, with five references to the OECD and one to the Global Partnership for Financial Inclusion (GPFI). No institutional references were made at the 2014 Brisbane summit. Only one was made at the 2015 Antalya summit - to the United Nations (UN).

Then in 2016 at Hangzhou, as with deliberation and decisions, there was a rise in performance. A peak of 59 references were made, 27 to internal institutions and 32 to external ones. The OECD, FSB, UN and GPFI remained on the list with several new ones added, such as the International Monetary Fund, World Trade Organization, the International Labour Organization and the civil society engagement group of the Business 20.

This momentum increased at the 2017 Hamburg summit which made 37 inside and 31 outside references, for a total of 68 institutional references. Here the World Bank Group, multilateral development banks and the African Union were added.

\section{Causes of G20 Digital Performance}

The task of identifying the causes of the G20's digital performance starts with an application of the six causes highlighted by the systemic hub model of G20 performance overall [Kirton, 2013].

\section{Shock-Activated Vulnerability}

The sharp spike in 2016-2017 may flow from new shock-activated vulnerabilities in the financial and political fields. The former includes theft of money from central banks and the surge in the use of digital payments through blockchain technology, which some feel was driven partly by its use for crime and corruption, money laundering, terrorist finance and sanctions busting from North Korea and elsewhere [Gapper, 2017]. Others were concerned with the use of digital technology to interfere in the electoral process of other countries. However, attention by the G20 to issues of digital security was low compared to those related to the digital economy and digital inclusion.

More broadly, the proliferating scale and scope of digital technology and automation has intensified the shared sense of vulnerability among G20 members in regard to their ability to 
create decent work and economic opportunities for all. Estimates of how many jobs might be lost due to automation vary widely. The OECD reports that on the high end nearly half of all jobs in the U.S. and other OECD countries could be lost to automation, while the OECD itself puts job losses at a much lower 9\% average [2016]. Job losses will be in specific sectors and may come in fewer than 5\% of occupations [Manyika et al., 2017]. Regardless, jobs will be lost mostly for the least-educated people in manual jobs, threatening to increase inequalities. Those who supported and continue to support the election of a populist and protectionist U.S. president during the 2016 elections are predominantly older, white, poorly educated blue-collar workers [Tyson, Maniam, 2016]. One poll shows that while these voters were actually financially secure, their children might not be [Rothwell, Diego-Rosell, 2016]. While the poll also looked at health and race as contributing factors, Trump's "America first" message appears not to have resonated with white blue-collar workers generally but with white blue -collar workers who fear that they will not be able to pass their financial security on to their children by sharing their knowledge of manual jobs as their own parents had been able to do for them. And while there is no similar study for the "Brexit" phenomena in the UK, the demographic split there is the same [Rosenbaun, 2017], suggesting the same worry was present. Thus, a contributing factor to the rise in populism and protectionism may be the old fear of a grim financial future for the young, or at least a future less bright than what had previously been imagined for them. The assumption of upward mobility for the next generation was broken among the working white. And with the benefits of digitalization unfamiliar, perceptions of certain insecurity and fears of being left behind remained strong.

The surfacing of these fears coincided with the G20's acceptance in 2016 and 2017 of the opportunities presented by digitalization and focus on the ways in which the G20 was best suited to cooperate to ensure those benefits were equitably distributed. The end of the G20's resistance to the digital age and the skills the world needs to "harness the digital transformation" was exemplified in Argentina's elevation of the future of work to the first of its three priorities for its 2018 Buenos Aires summit.

\section{Multilateral Organizational Failure}

Multilateral organizational failure also contributed to the G20's small but surging performance. On labour and employment and the future of work, the International Labour Organization (ILO) had been active with its Future of Work Initiative, the second phase of whichwas launched on 21 August 2017 by the prime minister of Sweden and president of Mauritius [ILO, n. d.]. The launch saw the high-level Global Commission on the Future of Work come to fruition. The Commission highlighted the ILO's work since 2015 to foster dialogue and identified the role of the Commission to produce an independent report on the future of work to be presented at the ILO's 2019 meeting. The ILO was thus working to advance the conversation and research on digitalization's impact on employment. However, it left a gap as it did not produce any tangible commitments that the world's countries chose to follow.

Beyond labour and employment, on the largely overlooked but critical issue of cyberspace governance, the venerable International Telecommunications Union (ITU), created in the 19th century to regulate the postal service, telegraphs and telephones, struggled to set rules for cyberspace. This was due to divisions between powerful members who preferred strong national government control and those who preferred internationally open, private sector-led regimes. In this vacuum, much innovation was driven by the Internet Corporation for Assigned Names and Numbers (ICANN), headquartered in and dominated by the United States. 
Moreover, on the first digital issue the G20 addressed - electronic trade - the most recent multilateral organizational failure was that of the WTO's 11th Ministerial Conference (MC-11) in Buenos Aires in December 2017, at which the WTO broke with past practice opting not to extend the two-decade long moratorium on imposing duties on electronic transmissions [Donnan, 2017b]. This step backward was led by India and other developing countries which, under the WTO's consensus rule, were able to prevent the previously routine extension. More broadly, the MC-11 did not agree to discuss new rules for e-commerce, "leading 70 of the WTO's 164 members, including the U.S. and EU and smaller economies such as Australia, to declare that they would pursue their own deal outside the WTO's usual negotiating stream" [Donnan, 2017b].

To a considerable extent, the growing performance of the G7 summit on digitalization compensated for (and may have been caused by) the G20's organizational failure. In the area of ICT, the G7 has been active since 1978 and almost continuously from 1981 to 2002 (see Appendix $\mathrm{H}$ ). Yet its performance declined to very low levels from 2008 to 2012, along with that of the G20. The G7's surge from 2013 to 2015 might help account for the G20's poor performance during that time.

There was also an intensification of G7-centred plurilateralism at MC-11, as the U.S., EU and Japan formed a new alliance to counter China's forced technology transfers, including its requirements to "hand over important proprietary technologies or house content and data on local servers" [Donnan, 2017a]. Yet even with its growing performance, the G7 excludes many of the already large and increasing digital powers led by China and India and even Russia since its suspension from the Group of 8 (G8) in 2014.

\section{Predominant Equalizing Capability}

The fourth cause - the G20's predominant equalizing capabilities - had some salience in explaining the slow, incomplete G20 performance, if not the 2016-17 spike. On the key specialized capability of governmental AI readiness, G7 countries led by the UK, U.S. and Canada took the top three spots, with France and Japan in the top seven. G20 members Korea and Australia were also in the top 10 (see Appendix I). However, even with Germany in 13th and Italy in 19th place only a minority of G20 members were in the top 20 . The other economically smaller members of the EU and OECD had this relevant specialized capability as well. This suggests that the smaller G7 and larger OECD might be better placed as global clubs to lead global governance on this issue.

More broadly, the 70 countries agreeing to launch negotiations for a plurilateral e-commerce agreement outside the WTO represented about $80 \%$ of global e-commerce trade [Donnan, 2017b].

\section{Converging Characteristics}

The convergence of the domestic characteristics of G20 members appears to be a salient cause, although inversely. The converging democratization of G20 members through to 2013 coincided with the G20's poor digital governance. The divergence since 2014, led by China's tighter control of its society and cyberspace, coincided with the G20's 2016 digital surge, starting at the Hangzhou summit itself. The surge also coincided with a widening of the digital divide. Indeed, while internet use in OECD countries has risen [OECD, 2014], digital inequality continues to rise both between and within both rich and poor countries [ITU,UNESCO, 2017]. 


\section{Domestic Political Cohesion}

The domestic political cohesion of G20 members and leaders is a partial fit. The surge in 20162017 came from both Chinese president Xi Jinping with high control over his government and German chancellor Angela Merkel who was in a coalition government and facing an election in two months. That said, she was a G20 veteran, the only scientist to serve as G20 host and a leader whose sherpa has advanced degrees in AI.

\section{Club at the Hub}

The sixth cause of performance is the "club at the hub," where the G20 club stands at the centre of a proliferating network of other actors and institutions and leaves leaders alone to be leaders through constricted and controlled participation [Kirton, 2013]. The reach of the hub can be measured first by identifying the number of leaders from nonmember countries and international organizations that participate at the G20 summits. This number has grown from six (two country leaders and four heads of international organizations) at Washington in 2008 to 15 (eight country leaders and seven heads of international organizations) at Hangzhou in 2016. This expansion is consistent with the expanding performance of the G20 on digitalization. Yet this increase does not fully account for the spike in performance at Hangzhou in 2016 as overall, few of the world's leading digital countries and international organizations, notably the ITU and ICANN, have been invited to G20 summits.

\section{Plans and Prospects for Buenos Aires, November 2018}

The three priorities Argentina chose for its presidency are the future of work, infrastructure for development and a sustainable food future. On the future of work Argentina identifies education as being at "the crux of the debate" stating that "education empowers people to shape their own future" [G20, 2017]. Argentina recognizes that rapid technological development poses significant challenges in terms of employment, welfare, education and inequalities, while simultaneously highlighting the path to the "fair and sustainable development" that the digital age offers. On the second priority of infrastructure for development, Argentina explicitly made the digital infrastructure connection, stating that infrastructure "provides the physical and digital access necessary for our citizens to seize the opportunities of the future economy." On the future of sustainable food, Argentina seeks "to promote a broad debate on the importance of sustainable soil management" to address food insecurity and the environmental consequences of soil degradation. In this context, digitizing agriculture for the modern era, for which the first commitment was made at the 2017 Hamburg summit, would also be on the agenda.

Under these three themes there are 11 thematic areas of which digital economy is one. Here Argentina will build on the work started at the 2015 Antalya summit that recognized the new digital era, the 2016 Hangzhou summit that set up a Digital Economy Task Force (DETF) and the 2017 Hamburg summit which officially established the DETF. It will apply a gender lens to its efforts on the digital economy, including in each of the five subcategories of digital inclusion: agricultural technology, future job skills, digital government, small- and mediumenterprises and industry 4.0. Additionally, the thematic area of employment will build on the work of the G20 Employment Working Group newly designed at Hamburg to focus on the future of work. Much work on digitalization will be done through the thematic area of education. Argentina has established the Education Working Group (EWG) whose work will focus on skills for life and work, especially in regard to "cognitive, non-cognitive and digital skills" and 
on financing. The EWG will meet four times, including once with the Labour Working Group, ahead of the education ministers' meeting on 5 September 2018, and the joint education and labour ministers' meeting on 6 September 2018. Digitalization and energy will also be a feature of the Argentinian presidency. However, the climate-digital connection has not been identified as a priority.

Argentina is thus likely to continue the rising trend in deliberation and decisions, and will perhaps raise the G20's delivery on digitalization. It will also likely continue to expand its development of global governance to include Latin American regional organizations. Importantly, Argentina may also help reverse the G20's steadily declining compliance on labour and employment with its focus on digital skills and thus help the G20 calm antiglobalist sentiments.

Argentina can, however, go further by applying its gender-focused lens not only to clear the path for women and girls to gain the digital skills needed to enter traditionally male-dominated jobs, but also to support and recognize the value of traditionally female-dominated jobs requiring the social skills that robots cannot yet mimic. Argentina should consider including men and boys in its education initiatives and could expand those education initiatives to include skills training in emotional intelligence that will have a high premium as humans live and work alongside artificial intelligence. This could go a long way toward addressing the root causes of gender-based inequalities.

Beyond gender, Argentina should also begin the conversation on the impacts of digital age policies on the environment and climate change, connecting digitalization to the climaterelated Sustainable Development Goals, including on food security, and to the Paris Agreement. In that way Argentina could respond to the central concern expressed by the influential respondents to the annual questionnaire for the World Economic Forum's Global Risks Report [WEF, 2017]. Here the list of the top five risks, in terms of both likelihood and impact, was dominated by climate change and its consequent extreme weather events and natural disasters, while digitalization in itself ranked much further down the list.

\section{Conclusion}

This study shows that the G20's governance of digitalization began at its first summit in Washington DC in 2008 with the issue of electronic trading, or e-commerce, identified as a tool for financial crisis management. Since then, the G20's attention to digitalization slowly expanded up to 2015. In 2016 a new phase began with the hosting of the G20 by China at Hangzhou. China's emphasis on the digital age reflected its ambitions in the world and relative capabilities in ICT. Its ambitions were also underpinned by citizens' discontent and rising inequalities in a declining U.S. and isolationist Britain, spurred by creative destruction and fears of an imagined dystopic robotic world [Kirton, 2016]. As global populist discontent solidified in 2017 so too did the G20's shift in response from one narrowly centred on e-trade and financial regulation to a human-focused, more forward-looking and inclusive narrative. At the 2017 Hamburg summit, the G20 built on the Hangzhou agenda by devoting much attention to fostering digital skills to generate employment, with a new and strong emphasis on the digital-gender divide. Here economic growth was at the fore front and issues of online harassment and social barriers for women and girls were also addressed for the first time. The G20 has thus chosen to accept that digitalization is here to stay and that it therefore must focus its energy not only on ensuring financial stability but on making digitalization work for all in an increasingly interconnected and globalized world.

Yet, thus far, the narrative reflected in the G20's deliberations, direction-setting and in its collective, future-oriented and politically obligatory commitments is incomplete. The greatest 
gap is on compliance with those commitments. Five commitments have been assessed for compliance on digitalization and the digital economy with four of those from the 2016 Hangzhou summit. Compliance is 50\% - well below the G20's overall average across all issue areas of $70 \%$. However, compliance may rise with the commitments made at Hamburg as gender equality has become a unifying issue across all G20 members, notably including Donald Trump's United States. Moreover, Argentina has identified the future of work as the first of the three priorities of its 2018 presidency. While Argentina's compliance across all issue areas is among the lowest of its G20 peers, on digitalization it comes in second place at $80 \%$, after only Canada's perfect compliance. There is therefore room for optimism that on digitalization Argentina will be a successful G20 summit consensus-builder as host.

\section{References}

Carin B. (2017) G20 Safeguards Digital Economy Vulnerabilities with a Financial Sector Focus. Economics: The Open-Access, Open Assessment E-Journal, vol. 11. Available at: http://www.economics-ejournal.org/economics/discussionpapers/2017-27 (accessed 18 April 2018).

Chetty K., Qigui L., Gcora N., Josie J., Wenwei L., Fang C. (2017) Bridging the Digital Divide: Measuring Digital Literacy. Economics Discussion Papers, No 2017-69, Kiel Institute for the World Economy. Available at: http://www.economics-ejournal.org/economics/discussionpapers/2017-69 (accessed 18 April 2018).

Donnan S. (2017a) US, EU and Japan to Link up on China Trade. Financial Times. 13 December, p. 2.

Donnan S. (2017b) WTO Wrestles with Relevance in Age of Ecommerce. Financial Times. 14 December. Available at: https://www.ft.com/content/d9f63c20-e01d-11e7-a8a4-0a1e63a52f9c (accessed 18 April 2018).

Gapper J. (2017) Bitcoin Casts a Shadow over Bank Payments. Financial Times. 14 December, p. 11.

G20 (2008) Declaration of the Summit on Financial Markets and the World Economy. 15 November. Available at: http://www.g20.utoronto.ca/2008/2008declaration1115.html (accessed 18 April 2018).

G20 (2010) The G20 Toronto Summit Declaration. 27 June. Available at: http://www.g20.utoronto.ca/2010/tocommunique.html (accessed 18 April 2018).

G20 (2015) G20 Leaders' Communiqué. 16 November. Available at: http://www.g20.utoronto.ca/2015/151116communique.html (accessed 18 April 2018).

G20 (2016) G20 Blueprint on Innovative Growth. 5 November. Available at: http://www.g20.utoronto. ca/2016/160905-blueprint.html (accessed 18 April 2018).

G20 (2017) Overview of Argentina's G20 Presidency in 2018. Available at: https://g20.org/en/g20-argentina/ priorities (accessed 18 December 2017).

G20 (2017a) G20 Leaders' Declaration: Shaping an Interconnected World. Available at: http://www.g20.utoronto. ca/2017/2017-G20-leaders-declaration.html (accessed 18 April 2018).

Global Wealth Report (2017) Global Wealth Report 2017. Credit Suisse Research Institute. Available at: https://www.credit-suisse.com/corporate/en/research/research-institute/global-wealth-report.html (accessed 18 April 2018).

ILO (n. d.) Global Commission on the Future of Work. Available at: http://www.ilo.org/global/topics/future-ofwork/WCMS_569528/lang--en/index.htm (accessed 18 December 2017).

ITU, UNESCO (2017) The State of Broadband: Broadband Catalyzing Sustainable Development. Broadband Commission for Sustainable Development, ITU and UNESCO (September). Available at: https://www.itu. int/dms_pub/itu-s/opb/pol/S-POL-BROADBAND.18-2017-PDF-E.pdf (accessed 18 April 2018).

Kirton J. (2013) G20 Governance for a Globalized World. Farnham: Ashgate.

Kirton J. (2016) China's G20 Leadership. Farnham: Ashgate.

Kirton J. (2017) A Summit of Solid Success at Hamburg in 2017. G20 Research Group. 8 July. Available at: http:// www.g20.utoronto.ca/analysis/170708-kirton-success.html (accessed 18 April 2018). 
Kirton J., Warren B. (2017) G20 Insights: T20 Recommendations Realized. G20 Research Group. 3 November. Available at: http://www.g20.utoronto.ca/analysis/t20-2017-recommendations-realized.html (accessed 18 April 2018).

Mariani S., Dionne M. (2017) "How Can the G20 Use AI to Help Create Sustainable Communities in an Inter-Connected World?” G20 Information Centre. 21 September. Available at: http://www.g7g20.utoronto.ca/ comment/170921-mariani-dionne.html (accessed 18 December 2017).

Maupin J. (2017) The G20 Countries Should Engage with Blockchain Technologies to Build an Inclusive, Transparent, and Accountable Digital Economy for All. Economic Discussions Papers, no 2017-48, Kiel Institute for the World Economy.

Manyika J., Chui M., Miremadi M., Bughin J., George K., Wilmott P., Dewhurst M. (2017) A Future That Works: Automation, Employment, and Productivity. McKinsey Global Institute (January).

OECD (2014) Measuring the Digital Economy: A New Perspective. Available at: http://dx.doi.org/10.1787/ 9789264221796-en (accessed 18 April 2018).

OECD (2016) Automation and Independent Work in a Digital Economy. Policy Brief on the Future of Work (May). Available at: https://www.oecd.org/els/emp/Policy\%20brief\%20-\%20Automation\%20and\%20Independent\%20Work\%20in\%20a\%20Digital\%20Economy.pdf (accessed 18 April 2018).

OECD (2016a) Ministerial Declaration on the Digital Economy. OECD 2016 Ministerial Meeting, The Digital Economy: Innovation, Growth and Social Prosperity. 21-23 June. Available at: https://www.oecd.org/internet/Digital-Economy-Ministerial-Declaration-2016.pdf (accessed 18 April 2018).

OECD (2017) Key Issues for Digital Transformation in the G20. Report Prepared for a Joint G20 German Presidency / OECD Conference. Berlin, Germany. 12 January. Available at: https://www.oecd.org/g20/keyissues-for-digital-transformation-in-the-g20.pdf (accessed 18 April 2018).

OECD (2017a) OECD Digital Economy Outlook 2017. Available at: http://dx.doi.org/10.1787/9789264276284en (accessed 18 April 2018).

Patel P. (2017) Will Automation Kill or Create Jobs? The Institute. 7 March. Available at: http://theinstitute. ieee.org/ieee-roundup/blogs/blog/will-automation-kill-or-create-jobs (accessed 18 December 2017).

Rosenbaum M. (2017) Local Voting Figures Shed New Light on EU Referendum. 6 February. Available at: http://www.bbc.com/news/uk-politics-38762034 (accessed 18 April 2018).

Rothwell J.T., Diego-Rosell P. (2016) Explaining Nationalist Political Views: The Case of Donald Trump. Gallup: George Washington University Institute of Public Policy. 2 November. Available at: https://papers.ssrn. com/sol3/papers.cfm?abstract_id=2822059 (accessed 18 December 2017).

Snower D. (2017) The G20 Summit was More Successful than You Think. G20 Insights. Available at: http:// www.g20-insights.org/2017/07/11/g20-summit-successful-think/ (accessed 18 April 2018).

Stirling R., Miller H., Truswell E.M. (2017) Government AI Readiness Index. Oxford Insights. 2017.

Tyson A., Maniam S. (2016) Behind Trump's Victory: Divisions by Race, Gender, Education. Pew Research Centre. 9 November. Available at: http://www.pewresearch.org/fact-tank/2016/11/09/behind-trumps-victorydivisions-by-race-gender-education/ (accessed 18 December 2017).

WEF (2017) Global Risks Report 2017. Available at: http://reports.weforum.org/global-risks-2017/ (accessed 18 April 2018). 


\section{Appendix A: G20 Summit Performance on Digitalization}

\begin{tabular}{|c|c|c|c|c|c|c|c|c|c|c|c|c|c|c|c|}
\hline \multirow{3}{*}{ Year } & \multicolumn{2}{|c|}{ DPM } & \multicolumn{3}{|c|}{ DEL } & \multicolumn{4}{|c|}{ DIR } & \multicolumn{2}{|c|}{ DEC } & \multicolumn{2}{|c|}{ DEL } & \multicolumn{2}{|c|}{ DGG } \\
\hline & \multirow[b]{2}{*}{ E } & \multirow[b]{2}{*}{ U } & \multicolumn{2}{|c|}{ Words } & \multirow[b]{2}{*}{ 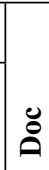 } & \multirow[b]{2}{*}{$\mathscr{L}$} & \multirow[b]{2}{*}{ 孞 } & \multirow[b]{2}{*}{ 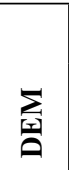 } & \multirow[b]{2}{*}{ 壬 } & \multirow{2}{*}{ 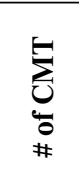 } & \multirow{2}{*}{ 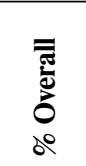 } & \multirow{2}{*}{ 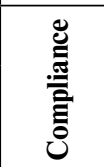 } & \multirow{2}{*}{ 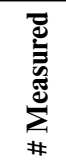 } & \multirow[b]{2}{*}{ Z } & \multirow[b]{2}{*}{5} \\
\hline & & & \# & $\%$ & & & & & & & & & & & \\
\hline $2008 \mathrm{~W}$ & 100 & 0 & 88 & 2 & 0 & 1 & 0 & 1 & 0 & 0 & 0 & $\mathrm{n} / \mathrm{a}$ & $\mathrm{n} / \mathrm{a}$ & 0 & 0 \\
\hline $2009 \mathrm{~L}$ & 100 & 0 & 0 & 0 & 0 & 0 & 0 & 0 & 0 & 0 & 0 & $\mathrm{n} / \mathrm{a}$ & $\mathrm{n} / \mathrm{a}$ & 0 & 0 \\
\hline $2009 \mathrm{P}$ & 100 & 0 & 289 & 3.12 & 0 & 7 & 0 & 2 & 0 & 0 & 0 & $\mathrm{n} / \mathrm{a}$ & $\mathrm{n} / \mathrm{a}$ & 1 & 1 \\
\hline 2010T & 100 & 0 & 229 & 2.07 & 0 & 2 & 0 & 1 & 0 & 0 & 0 & $\mathrm{n} / \mathrm{a}$ & $\mathrm{n} / \mathrm{a}$ & 0 & 0 \\
\hline $2010 S$ & 100 & 0 & 0 & 0 & 0 & 0 & 0 & 0 & 0 & 0 & 0 & $\mathrm{n} / \mathrm{a}$ & $\mathrm{n} / \mathrm{a}$ & 0 & 0 \\
\hline $2011 \mathrm{C}$ & 95 & 0 & 372 & 2.64 & 0 & 4 & 0 & 0 & 0 & 1 & 0.35 & - & - & 0 & 7 \\
\hline 2012LC & 95 & 0 & 169 & 1.33 & 0 & 2 & 0 & 0 & 0 & 0 & 0 & $\mathrm{n} / \mathrm{a}$ & $\mathrm{n} / \mathrm{a}$ & 1 & 1 \\
\hline 2013SP & 95 & 0 & 760 & 2.64 & 0 & 0 & 2 & 0 & 0 & 0 & 0 & $\mathrm{n} / \mathrm{a}$ & $\mathrm{n} / \mathrm{a}$ & 7 & 6 \\
\hline 2014B & 90 & 0 & 0 & 0 & 0 & 0 & 0 & 0 & 0 & 0 & 0 & $\mathrm{n} / \mathrm{a}$ & $\mathrm{n} / \mathrm{a}$ & 0 & 0 \\
\hline $2015 \mathrm{~A}$ & 90 & 0 & 299 & 2.15 & 0 & 2 & 1 & 0 & 2 & 0 & 0 & $\mathrm{n} / \mathrm{a}$ & $\mathrm{n} / \mathrm{a}$ & 0 & 1 \\
\hline $2016 \mathrm{Ch}$ & 95 & 0 & 3042 & 18.77 & 0 & 12 & 35 & 11 & 1 & 29 & 13.62 & -0.04 & 4 & 27 & 32 \\
\hline $2017 \mathrm{H}$ & 95 & 0 & 5029 & 14.47 & 0 & 18 & 77 & 8 & 1 & 25 & 4.71 & - & - & 37 & 31 \\
\hline Total & 1060 & 0 & 10277 & 49.19 & 0 & 48 & 115 & 23 & 4 & 55 & 18.68 & - & 4 & 73 & 79 \\
\hline Average & 96.36 & 0 & 856.42 & 4.10 & 0 & 4 & 9.58 & 1.92 & 0.33 & 4.58 & 1.56 & -0.04 & - & 6.08 & 6.58 \\
\hline
\end{tabular}

Notes.

DPM: Domestic Political Management - measured by the number of leaders in attendance (Att) and communiqué compliments (CC), the number of times a country or leader was positively mentioned.

DEL: Deliberation - measured by the number of words on the subject (\#), the percent (\%) of words and the number of dedicated documents to the issue (Doc).

DIR: Direction setting - measured by the number of references to the G20 financial stability principle (FS), globalization for all (GFA), the G8 democratic principles (Dem) and human rights (HR).

DEC: Decisions - measured by the number of commitments (CMT) and the percentage of overall commitments (\% overall).

DVY: Delivery - measured by compliance with priority commitments $(\mathrm{Cmp})$ and the number of compliance reports (\# measured).

DGG: Development of Global Governance - measured by the number of references to governance mechanisms developed within the G20 (IN) and the number to governance mechanisms developed outside of the G20 (OUT).

Overall: Overall grade.

n/a $=$ not applicable $;-=$ no commitment assessed.

One related digitalization commitment was assessed in 2015 on the digital divide with compliance at +0.10 . Added to the four commitments assessed from 2016, compliance is 0 or $50 \%$. 


\section{Appendix B: G20 Leaders' Conclusions on Digital Economy, 2008-2017}

\begin{tabular}{|c|c|c|c|c|c|c|c|}
\hline Year & 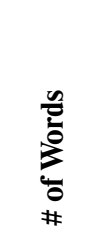 & 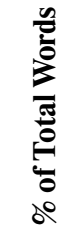 & 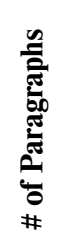 & 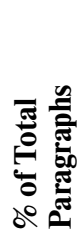 & 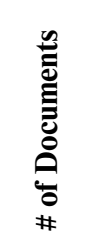 & 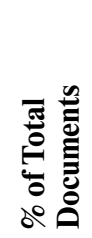 & 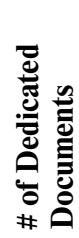 \\
\hline 2008 Washington & 88 & 2 & 1 & 1.22 & 1 & 50 & 0 \\
\hline 2009 London & 0 & 0 & 0 & 0 & 0 & 0 & 0 \\
\hline 2009 Pittsburgh & 289 & 3.12 & 1 & 0.78 & 1 & 33.33 & 0 \\
\hline 2010 Toronto & 229 & 2.07 & 2 & 1.04 & 2 & 40 & 0 \\
\hline 2010 Seoul & 0 & 0 & 0 & 0 & 0 & 0 & 0 \\
\hline 2011 Cannes & 372 & 2.64 & 2 & 1.32 & 2 & 66.67 & 0 \\
\hline 2012 Los Cabos & 169 & 1.33 & 1 & 0.49 & 1 & 25 & 0 \\
\hline 2013 St. Petersburg & 760 & 2.64 & 5 & 0.94 & 3 & 27.27 & 0 \\
\hline 2014 Brisbane & 0 & 0 & 0 & 0 & 0 & 0 & 0 \\
\hline 2015 Antalya & 299 & 2.15 & 2 & 0.57 & 2 & 33.33 & 0 \\
\hline 2016 Hangzhou & 3042 & 18.77 & 21 & 3.00 & 4 & 100 & 0 \\
\hline 2017 Hamburg & 5029 & 14.47 & 55 & 3.21 & 7 & 70 & 0 \\
\hline Average & 856.42 & 4.10 & 7.50 & 1.05 & 1.917 & 37.13 & 0 \\
\hline
\end{tabular}

Notes.

Data are drawn from all official English-language documents released by the G20 leaders as a group. Charts are excluded.

"\# of Words" is the number of subjects related to the digital economy for the year specified, excluding document titles and references. Words are calculated by paragraph because the paragraph is the unit of analysis.

"\% of Total Words" refers to the total number of words in all documents for the year specified.

"\# of Paragraphs" is the number of paragraphs containing references to the digital economy for the year specified. Each point is recorded as a separate paragraph.

"\% of Total Paragraphs" refers to the total number of paragraphs in all documents for the year specified.

"\# of Documents" is the number of documents that contain the digital economy subjects and excludes dedicated documents.

"\% of Total Documents" refers to the total number of documents for the year specified.

"\# of Dedicated Documents" is the number of documents for the year that contain a subject related to the digital economy in the title. 


\section{Appendix C: G20 Summit Direction-Setting Digital Economy, 2013-2017}

\begin{tabular}{|c|c|c|c|c|c|c|c|c|c|c|c|c|c|}
\hline Value & $\vec{E}$ & 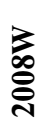 & 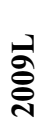 & 응 & 흘 & 芫 & $\stackrel{\cup}{\bar{\gamma}}$ & 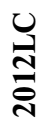 & 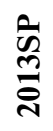 & $\stackrel{\varphi}{\vec{\nabla}}$ & 艿 & $\frac{\mathbb{T}}{0}$ & 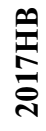 \\
\hline Financial Stability & 48 & 1 & 0 & 7 & 2 & 0 & 4 & 2 & 0 & 0 & 2 & 12 & 18 \\
\hline $\begin{array}{l}\text { Financial Stability } \\
\text { Board }\end{array}$ & 13 & 0 & 0 & 1 & 0 & 0 & 3 & 1 & 0 & 0 & 0 & 5 & 3 \\
\hline Financial Stability & 4 & 0 & 0 & 0 & 0 & 0 & 0 & 0 & 0 & 0 & 1 & 0 & 3 \\
\hline Crisis Prevention & 1 & 0 & 0 & 1 & 0 & 0 & 0 & 0 & 0 & 0 & 0 & 0 & 0 \\
\hline Risk Management & 15 & 1 & 0 & 5 & 1 & 0 & 0 & 0 & 0 & 0 & 1 & 3 & 4 \\
\hline Resilience & 10 & 0 & 0 & 0 & 1 & 0 & 1 & 1 & 0 & 0 & 0 & 2 & 5 \\
\hline Address Vulnerabilities & 3 & 0 & 0 & 0 & 0 & 0 & 0 & 0 & 0 & 0 & 0 & 2 & 1 \\
\hline Shock Management & 2 & 0 & 0 & 0 & 0 & 0 & 0 & 0 & 0 & 0 & 0 & 0 & 2 \\
\hline $\begin{array}{l}\text { Globalization } \\
\text { for the Benefit of All }\end{array}$ & 109 & 0 & 0 & 0 & 0 & 0 & 0 & 0 & 2 & 0 & 1 & 35 & 77 \\
\hline Digital Inclusion & 44 & 0 & 0 & 0 & 0 & 0 & 0 & 0 & 1 & 0 & 0 & 17 & 26 \\
\hline Access & 17 & 0 & 0 & 0 & 0 & 0 & 0 & 0 & 1 & 0 & 0 & 4 & 12 \\
\hline Poor / Low Income & 11 & 0 & 0 & 0 & 0 & 0 & 0 & 0 & 0 & 0 & 0 & 3 & 8 \\
\hline $\begin{array}{l}\text { Bridge the } \\
\text { (Digital Divide) }\end{array}$ & 13 & 0 & 0 & 0 & 0 & 0 & 0 & 0 & 0 & 0 & 1 & 2 & 10 \\
\hline All People & 8 & 0 & 0 & 0 & 0 & 0 & 0 & 0 & 0 & 0 & 0 & 3 & 5 \\
\hline $\begin{array}{l}\text { Vulnerable/ } \\
\text { Underserved Groups }\end{array}$ & 8 & 0 & 0 & 0 & 0 & 0 & 0 & 0 & 0 & 0 & 0 & 1 & 7 \\
\hline $\begin{array}{l}\text { Support Developing } \\
\text { Countries }\end{array}$ & 8 & 0 & 0 & 0 & 0 & 0 & 0 & 0 & 0 & 0 & 0 & 5 & 9 \\
\hline Open Democracy & 23 & 1 & 0 & 2 & 1 & 0 & 0 & 0 & 0 & 0 & 0 & 11 & 8 \\
\hline Open & 11 & 0 & 0 & 0 & 0 & 0 & 0 & 0 & 0 & 0 & 0 & 9 & 2 \\
\hline Transparent & 12 & 1 & 0 & 2 & 1 & 0 & 0 & 0 & 0 & 0 & 0 & 2 & 6 \\
\hline Human Rights & 4 & 0 & 0 & 0 & 0 & 0 & 0 & 0 & 0 & 0 & 2 & 1 & 1 \\
\hline Human Rights & 3 & 0 & 0 & 0 & 0 & 0 & 0 & 0 & 0 & 0 & 1 & 1 & 1 \\
\hline International Law & 1 & 0 & 0 & 0 & 0 & 0 & 0 & 0 & 0 & 0 & 1 & 0 & 0 \\
\hline
\end{tabular}

Note: Compiled by Alecs Dragus, 12 December 2017.

The unit of analysis is the sentence.

"Financial stability" includes references to the financial stability/stabilization, stabilizing the impact of financial crises, prevent future crisis, risk/risk management, resilience, financial recovery, financial sustainability and the FSF/FSB.

Exclusions: General reference to a crisis and another crisis that is not the global financial crisis.

"Globalization for all" includes references to digital inclusion/Digital Financial Inclusion, Global Partnership for Financial Inclusion (GPFI), GPFI Guidance Note on Building Inclusive Digital Payments Ecosystem, inclusive/inclusiveness, global growth, globalization for the benefit of all, inclusive growth, 
inclusiveness, inclusion, poorest, poor, vulnerable and most vulnerable groups, excluded and underserved groups, least developed countries (in the context of enhancing their development), economic growth that meets everyone's needs, inclusive world economy, all parts of the globe/all people, gap between rich and poor, and the Global Partnership for Financial Inclusion.

Exclusions: Least developed countries, broadly shared growth, and wide-spread growth.

"Democracy" includes references to democracy, freedom, free and fair elections, religious freedom, openness/open, transparency, transparent digital economy, open government and open.

"Human Rights/Individual Liberty" includes references to "rights" and "law." "Rights" includes human rights, sexual and reproductive rights, rights for all, women's rights and fundamental rights. "Law" includes a free and fair trial, rule of law, international law and humanitarian law.

\section{Appendix D: G20 Digital Economy Commitments and Compliance 2015-2017}

\begin{tabular}{|l|c|c|l|c|c|}
\hline $\begin{array}{c}\text { Core Digital } \\
\text { Economy }\end{array}$ & Compliance & $\begin{array}{c}\text { Commitments } \\
\text { Assessed/Made }\end{array}$ & Other Digitalization & Compliance & $\begin{array}{c}\text { Commitments } \\
\text { Assessed/Made }\end{array}$ \\
\hline 2008 Washington & & $0 / 1$ & 2008 Washington & - & - \\
\hline 2009 London & - & - & 2009 London & - & - \\
\hline 2009 Pittsburgh & - & - & 2009 Pittsburgh & - & - \\
\hline 2010 Toronto & - & - & 2010 Toronto & - & - \\
\hline 2010 Seoul & - & - & 2010 Seoul & - & - \\
\hline 2011 Cannes & & $0 / 1$ & 2011 Cannes & - & - \\
\hline 2012 Los Cabos & & $0 / 1$ & 2012 Los Cabos & - & - \\
\hline 2013 St. Petersburg & & $0 / 1$ & 2013 St. Petersburg & - & - \\
\hline 2014 Brisbane & - & - & 2014 Brisbane & - & - \\
\hline 2015 Antalya & - & - & 2015 Antalya & +0.10 & $1 / 1$ \\
\hline 2016 Hangzhou & -0.04 & $4 / 29$ & 2016 Hangzhou & - & - \\
\hline 2017 Hamburg & & $0 / 25$ & 2017 Hamburg & & $0 / 29$ \\
\hline Total/Average & -0.04 & 58 & Total/Average & +0.10 & 30 \\
\hline
\end{tabular}

Notes.

Combined average is +0.03 or $52 \%$.

Blank cell $=$ no commitments assessed $;-=$ not applicable . 


\section{Appendix D-1: G20 Assessed Digitalization Commitments}

2015-93: We commit ourselves to bridge the digital divide.

2016-160: [We are committed to unleashing the potential of the digital economy by providing favourable conditions for its development, including reaffirming the goal of ensuring the next 1.5 billion people are connected and have meaningful access to the Internet by 2020 in accordance with the Connect 2020 agenda through] supporting entrepreneurship.

2016-161: [We are committed to unleashing the potential of digital economy by providing favourable conditions for its development, including reaffirming the goal of ensuring the next 1.5 billion people are connected and have meaningful access to the Internet by 2020 in accordance with the Connect 2020 agenda, through] encouraging e-commerce cooperation.

2016-163: [We are committed to unleashing the potential of the digital economy by providing favourable conditions for its development, including reaffirming the goal of ensuring the next 1.5 billion people are connected and have meaningful access to the Internet by providing favourable conditions for its development, including affirming the goal of ensuring the next 1.5 billion people are connected and have meaningful access to the Internet by 2020 in accordance with the Connect 2020 agenda, through] promoting policies that support MSMEs to use ICT technology more effectively. 


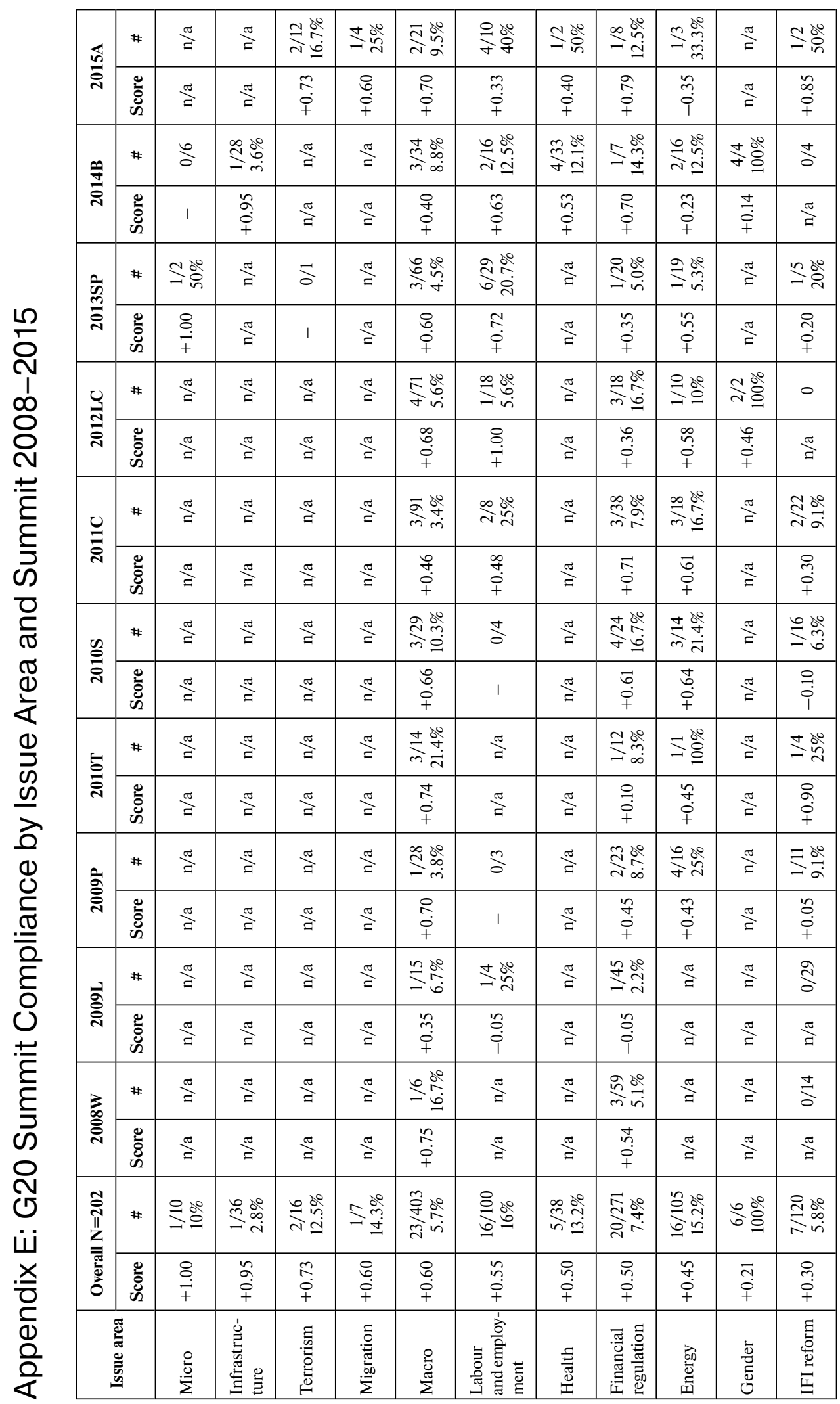




\begin{tabular}{|c|c|c|c|c|c|c|c|c|c|c|c|}
\hline \multirow{2}{*}{ 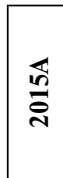 } & $\#$ & $\stackrel{m}{=} \underset{m}{m}$ & ì in & $\stackrel{m}{\delta}$ & $\stackrel{\Delta}{\stackrel{i}{i}} \underset{i}{\stackrel{i}{i}}$ & $\partial$ & 这 & S & $\stackrel{\pi}{\Omega}$ & $\begin{array}{l}\stackrel{0}{*} \text { 。o } \\
\text { in }\end{array}$ & 兽 \\
\hline & 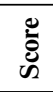 & $\begin{array}{l}9 \\
0 \\
1\end{array}$ & \begin{tabular}{l} 
足 \\
\multirow{+}{+}{} \\
+
\end{tabular} & 1 & $\begin{array}{l}8 \\
0 \\
+\end{array}$ & & $\begin{array}{l}n \\
? \\
+\end{array}$ & $\begin{array}{l}\stackrel{9}{0} \\
+ \\
+\end{array}$ & $\stackrel{\pi}{\Omega}$ & 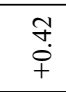 & $\overline{\mathrm{z}}$ \\
\hline \multirow{2}{*}{$\stackrel{\varphi}{\tilde{\nabla}}$} & $\#$ & $\stackrel{\pi}{\Xi}$ & 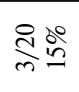 & 络 & 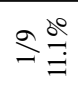 & $\partial$ & $\stackrel{\Delta}{\sigma}$ & $\stackrel{\pi}{\Xi}$ & $\stackrel{\pi}{\Xi}$ & 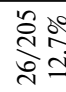 & \\
\hline & 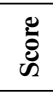 & $\stackrel{\pi}{a}$ & \begin{tabular}{l}
$\infty$ \\
\multirow{3}{0}{} \\
+ \\
+
\end{tabular} & $\begin{array}{l}\bar{n} \\
\vdots \\
+\end{array}$ & \begin{tabular}{l}
$n$ \\
\multirow{1}{n}{} \\
+ \\
+
\end{tabular} & & I & $\stackrel{\pi}{\Omega}$ & $\stackrel{\pi}{a}$ & $\begin{array}{l}\text { fo } \\
+ \\
+\end{array}$ & \\
\hline \multirow{2}{*}{$\begin{array}{l}\bar{n} \\
\frac{\pi}{3}\end{array}$} & $\#$ & $\vec{\Sigma} \frac{\dot{0}}{a}$ & 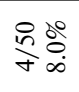 & 길 & 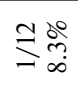 & $\partial$ & 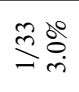 & $\stackrel{\pi}{=}$ & $\bar{\delta}$ & 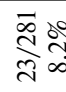 & $=$ \\
\hline & 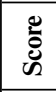 & $\begin{array}{l}\infty \\
\infty \\
0 \\
+ \\
\end{array}$ & $\begin{array}{l}+ \\
\\
0 \\
\\
\end{array}$ & $\begin{array}{l}7 \\
i \\
\end{array}$ & $\begin{array}{l}n \\
\tilde{m} \\
i \\
i\end{array}$ & & $\begin{array}{l}n \\
9 \\
+\end{array}$ & $\stackrel{\pi}{=}$ & $\stackrel{\pi}{\beth}$ & $\begin{array}{l}\hat{\sigma} \\
\dot{+} \\
+\end{array}$ & \\
\hline \multirow{2}{*}{ ב্ড, } & $\#$ & 过 & $\underset{m}{\stackrel{0}{2}} \stackrel{0}{\circ}$ & in & $\stackrel{9}{2} \stackrel{0}{=}$ & $\partial$ & $\stackrel{\text { 离 }}{=}$ & $\stackrel{\pi}{\Xi}$ & $\bar{\sigma}$ & 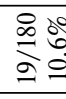 & \\
\hline & 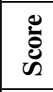 & 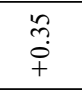 & $\begin{array}{l}\infty \\
\\
\dot{\phi} \\
+\end{array}$ & $\begin{array}{l}\text { nे } \\
\text { के } \\
+\end{array}$ & 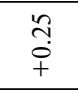 & & $\begin{array}{l}0 \\
0 \\
i\end{array}$ & $\stackrel{\pi}{=}$ & $\stackrel{\pi}{\beth}$ & 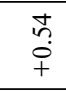 & \\
\hline \multirow{2}{*}{ ํㅡㄹ } & $\#$ & $\begin{array}{l}\text { D } \\
\text { di } \\
\text { in }\end{array}$ & $\underset{\sim}{\stackrel{\infty}{\infty}} \stackrel{\infty}{=}$ & $\begin{array}{c}\infty \\
m \\
m\end{array}$ & $\stackrel{n}{=} \underset{0}{\frac{2}{6}}$ & $\lambda$ & $\stackrel{n}{o}$ & $\stackrel{\pi}{\Xi}$ & $\Sigma$ & 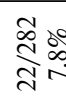 & \\
\hline & 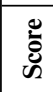 & $\begin{array}{l}n \\
\hat{+} \\
+\end{array}$ & $\begin{array}{l}\tilde{m} \\
\dot{+}\end{array}$ & $\begin{array}{l}\infty \\
\stackrel{+}{+} \\
+\end{array}$ & $\begin{array}{l}\stackrel{1}{0} \\
\vdots \\
+\end{array}$ & 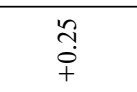 & 1 & $\stackrel{\pi}{\Xi}$ & 1 & $\begin{array}{l}\text { fे } \\
\text { 字 }\end{array}$ & \\
\hline \multirow{2}{*}{ ஜै } & $\#$ & $\delta$ & స్తి & $\stackrel{\infty}{\Rightarrow} \stackrel{\circ}{\circ}$ & $\begin{array}{l}=80 \\
=\text { in }\end{array}$ & $>$ & $\stackrel{30}{\rightarrow}$ & $\stackrel{\pi}{\Xi}$ & $\stackrel{\pi}{\Xi}$ & 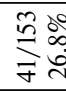 & \\
\hline & 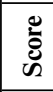 & 1 & $\begin{array}{l}\bar{m} \\
\dot{0} \\
+\end{array}$ & $\begin{array}{l}0 \\
0 \\
0 \\
+ \\
\end{array}$ & $\begin{array}{l}n \\
0 \\
i \\
i\end{array}$ & $\begin{array}{l}n \\
0 \\
0 \\
+\end{array}$ & 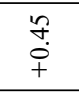 & $\stackrel{\pi}{\beth}$ & $\stackrel{\pi}{\beth}$ & $\begin{array}{l}+ \\
\stackrel{+}{+} \\
+\end{array}$ & \\
\hline \multirow{2}{*}{ 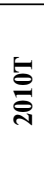 } & $\#$ & So & $\underset{m}{\infty} \underset{m}{\infty}$ & mळ̊ & $\stackrel{2}{2} \stackrel{0}{=}$ & $\partial$ & 욜 & $\stackrel{\pi}{=}$ & $\stackrel{\pi}{=}$ & 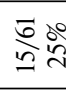 & \\
\hline & 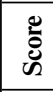 & \begin{tabular}{l} 
\\
\multirow{1}{0}{} \\
+ \\
\end{tabular} & $\begin{array}{l}3 \\
\tilde{+} \\
+ \\
+\end{array}$ & 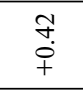 & $\begin{array}{l}\stackrel{n}{0} \\
0 \\
+\end{array}$ & & $\begin{array}{l}\text { ì } \\
\text { in } \\
\end{array}$ & $\stackrel{\pi}{\Xi}$ & $\stackrel{\pi}{\Xi}$ & 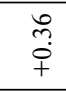 & \\
\hline \multirow{2}{*}{ ڤิे } & $\#$ & $\hat{\sigma}$ & ब্লm & 일 & $\stackrel{0}{\circ} \stackrel{0}{6}$ & $\partial$ & ৯용 & $\stackrel{\pi}{\Xi}$ & $\stackrel{\pi}{=}$ & 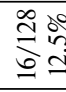 & \\
\hline & 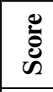 & 1 & $\begin{array}{l}9 \\
\vdots \\
+ \\
+\end{array}$ & $\begin{array}{l}\infty \\
0 \\
+ \\
+\end{array}$ & 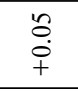 & & 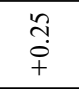 & $\stackrel{\pi}{a}$ & $\stackrel{\Xi}{\Xi}$ & $\vec{m}$ & \\
\hline \multirow{2}{*}{ ڤิे } & $\#$ & $\stackrel{\pi}{=}$ & 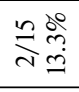 & 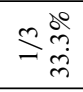 & $\stackrel{ \pm}{\triangle} \stackrel{0}{\therefore}$ & $\partial$ & $\stackrel{\pi}{=}$ & $\stackrel{\pi}{=}$ & $\stackrel{\pi}{=}$ & ิㅗㅇㅇㅝ & \\
\hline & \begin{tabular}{|l|}
\multicolumn{2}{c}{} \\
صั \\
\end{tabular} & $\stackrel{\pi}{=}$ & $\begin{array}{l}0 \\
0 \\
+ \\
+\end{array}$ & $\begin{array}{l}9 \\
\vdots \\
\end{array}$ & 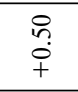 & & $\stackrel{\pi}{=}$ & $\stackrel{\pi}{=}$ & $\stackrel{\pi}{=}$ & $\begin{array}{l}9 \\
+ \\
+\end{array}$ & \\
\hline \multirow{2}{*}{ 商 } & \# & $\stackrel{\pi}{g}$ & $\stackrel{\Delta}{\Delta}$ & $\stackrel{\pi}{\Xi}$ & 잉 & $\partial$ & $\delta$ & $\stackrel{\pi}{\Xi}$ & 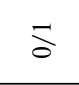 & $\stackrel{2}{\infty} \frac{j}{\infty}$ & \\
\hline & 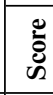 & $\stackrel{\pi}{=}$ & $\begin{array}{l}\infty \\
\infty \\
0 \\
+\end{array}$ & $\stackrel{\pi}{\Omega}$ & กิ & & 1 & $\stackrel{\pi}{\Xi}$ & 1 & $\begin{array}{l}0 \\
\stackrel{n}{+} \\
+ \\
\end{array}$ & \\
\hline \multirow{2}{*}{ 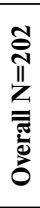 } & \# & 声 do & $\underset{F}{\stackrel{2}{2} \stackrel{\circ}{+}}$ & 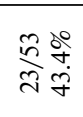 & 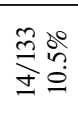 & $\lambda$ & $\stackrel{\infty}{\stackrel{\infty}{2}} \stackrel{0}{\circ}$ & 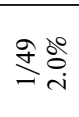 & $\stackrel{ \pm}{\sigma}$ & 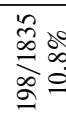 & $\bar{\sigma}$ \\
\hline & 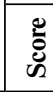 & $\begin{array}{l}\text { ले } \\
\hat{+}\end{array}$ & $\begin{array}{l}\bar{m} \\
\dot{+}\end{array}$ & $\begin{array}{l}\bar{m} \\
\dot{+} \\
+\end{array}$ & 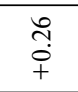 & $\begin{array}{l}2 \\
0 \\
+\end{array}$ & 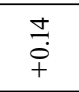 & $\begin{array}{l}9 \\
\vdots \\
+\end{array}$ & 1 & $\begin{array}{l}\stackrel{9}{9} \\
\dot{+}\end{array}$ & \\
\hline \multicolumn{2}{|c|}{ 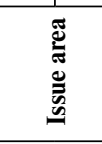 } & 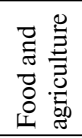 & 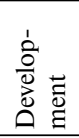 & 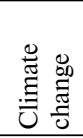 & 䞤 & 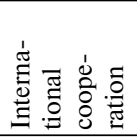 & 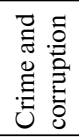 & $\underline{\underline{v}}$ & 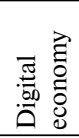 & 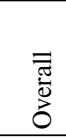 & \\
\hline
\end{tabular}




\section{Appendix F: G20 Development of Global Governance 2008-2017}

\begin{tabular}{|l|c|c|c|}
\hline \multicolumn{1}{|c|}{ Summit } & Internal & External & Total \\
\hline 2008 Washington & 0 & 0 & 0 \\
\hline 2009 London & 0 & 0 & 2 \\
\hline 2009 Pittsburgh & 1 & 1 & 0 \\
\hline 2010 Toronto & 0 & 0 & 0 \\
\hline 2010 Seoul & 0 & 0 & 7 \\
\hline 2011 Cannes & 0 & 7 & 2 \\
\hline 2012 Los Cabos & 1 & 1 & 13 \\
\hline 2013 St. Petersburg & 7 & 6 & 0 \\
\hline 2014 Brisbane & 0 & 0 & 59 \\
\hline 2015 Antalya & 0 & 1 & 68 \\
\hline 2016 Hangzhou & 27 & 32 & 152 \\
\hline 2017 Hamburg & 37 & 31 & \\
\hline Total & 73 & 79 & \\
\hline
\end{tabular}

Appendix H: G8 Conclusions on Information and Communications Technologies (ICT), 1975-2015

\begin{tabular}{|l|c|c|c|c|c|c|c|}
\hline Year & $\begin{array}{c}\text { \# of } \\
\text { Words }\end{array}$ & $\begin{array}{c}\text { \% of Total } \\
\text { Words }\end{array}$ & $\begin{array}{c}\text { \# of } \\
\text { Paragraphs }\end{array}$ & $\begin{array}{c}\text { \% of Totals } \\
\text { Paragraphs }\end{array}$ & $\begin{array}{c}\text { \# of } \\
\text { Documents }\end{array}$ & $\begin{array}{c}\text { \% of Total } \\
\text { Documents }\end{array}$ & $\begin{array}{c}\text { \# of } \\
\text { Dedicated } \\
\text { Documents }\end{array}$ \\
\hline 1975 & 0 & 0 & 0 & 0 & 0 & 0 & 0 \\
\hline 1976 & 0 & 0 & 0 & 0 & 0 & 0 & 0 \\
\hline 1977 & 0 & 0 & 0 & 0 & 0 & 0 & 0 \\
\hline 1978 & 46 & 1.5 & 1 & 2.0 & 1 & 50 & 0 \\
\hline 1979 & 0 & 0 & 0 & 0 & 0 & 0 & 0 \\
\hline 1980 & 0 & 0 & 0 & 0 & 0 & 0 & 0 \\
\hline 1981 & 61 & 1.9 & 1 & 1.9 & 1 & 33.3 & 0 \\
\hline 1982 & 183 & 10.1 & 2 & 10 & 1 & 50 & 0 \\
\hline 1983 & 34 & 1.5 & 1 & 2.7 & 1 & 50 & 0 \\
\hline 1984 & 171 & 5.2 & 4 & 8.2 & 1 & 20 & 0 \\
\hline 1985 & 422 & 13.4 & 7 & 16.7 & 1 & 50 & 0 \\
\hline 1986 & 201 & 5.6 & 3 & 9.3 & 1 & 25 & 0 \\
\hline 1987 & 55 & 1.1 & 1 & 1.4 & 1 & 14.2 & 0 \\
\hline 1988 & 165 & 3.3 & 3 & 4.6 & 1 & 33.3 & 0 \\
\hline 1989 & 52 & 0.7 & 1 & 0.8 & 1 & 9.0 & 0 \\
\hline 1990 & 112 & 1.5 & 2 & 1.6 & 1 & 25 & 0 \\
\hline 1991 & 69 & 0.9 & 1 & 1.8 & 1 & 20 & 0 \\
\hline 1992 & 0 & 0 & 0 & 0 & 0 & 0 & 0 \\
\hline & & & & & & & \\
\hline
\end{tabular}




\begin{tabular}{|l|c|c|c|c|c|c|c|}
\hline Year & $\begin{array}{c}\text { \# of } \\
\text { Words }\end{array}$ & $\begin{array}{c}\text { \% of Total } \\
\text { Words }\end{array}$ & $\begin{array}{c}\text { \# of } \\
\text { Paragraphs }\end{array}$ & $\begin{array}{c}\text { \% of Totals } \\
\text { Paragraphs }\end{array}$ & $\begin{array}{c}\text { \# of } \\
\text { Documents }\end{array}$ & $\begin{array}{c}\text { \% of Total } \\
\text { Documents }\end{array}$ & $\begin{array}{c}\text { \# of } \\
\text { Dedicated } \\
\text { Documents }\end{array}$ \\
\hline 1993 & 53 & 1.5 & 1 & 2.3 & 1 & 33.3 & 0 \\
\hline 1994 & 26 & 0.6 & 3 & 4.4 & 1 & 50 & 0 \\
\hline 1995 & 226 & 3.1 & 3 & 2.2 & 1 & 33.3 & 0 \\
\hline 1996 & 287 & 1.9 & 2 & 1.0 & 2 & 40 & 0 \\
\hline 1997 & 258 & 2.0 & 1 & 0.7 & 1 & 20 & 0 \\
\hline 1998 & 87 & 1.4 & 1 & 1.6 & 1 & 25 & 0 \\
\hline 1999 & 196 & 1.9 & 3 & 2.5 & 2 & 50 & 0 \\
\hline 2000 & 3020 & 22.2 & 23 & 15.8 & 2 & 40 & 1 \\
\hline 2001 & 176 & 2.8 & 2 & 2.7 & 1 & 14.2 & 0 \\
\hline 2002 & 59 & 0.5 & 1 & 0.6 & 1 & 14.2 & 0 \\
\hline 2003 & 0 & 0 & 0 & 0 & 0 & 0 & 0 \\
\hline 2004 & 34 & 0.1 & 1 & 0.2 & 1 & 5 & 0 \\
\hline 2005 & 0 & 0 & 0 & 0 & 0 & 0 & 0 \\
\hline 2006 & 118 & 0.5 & 2 & 0.6 & 2 & 13.3 & 0 \\
\hline 2007 & 45 & 0.2 & 1 & 0.6 & 1 & 11.1 & 0 \\
\hline 2008 & 0 & 0 & 0 & 0 & 0 & 0 & 0 \\
\hline 2009 & 175 & 1.0 & 2 & 0.6 & 1 & 7.6 & 0 \\
\hline 2010 & 0 & 0 & 0 & 0 & 0 & 0 & 0 \\
\hline 2011 & 604 & 3.3 & 5 & 2.3 & 2 & 40 & 0 \\
\hline 2012 & 155 & 1.3 & 3 & 1.6 & 2 & 33.3 & 0 \\
\hline 2013 & 2498 & 18.5 & 62 & 23.3 & 3 & 75 & 1 \\
\hline 2014 & 487 & 9.5 & 4 & 5.6 & 1 & 100 & 0 \\
\hline 2015 & 1835 & 21.9 & 18 & 13.4 & 2 & 100 & 0 \\
\hline Average & 297.75 & 3.39 & 4.12 & 3.57 & 1 & 27.12 & 0.05 \\
\hline
\end{tabular}

Notes.

Data are drawn from all official English-language documents released by the G7/G8 leaders as a group. Charts are excluded.

"\# of Words" is the number of ICT-related subjects for the year specified, excluding document titles and references. Words are calculated by paragraph because the paragraph is the unit of analysis.

"\% of Total Words" refers to the total number of words in all documents for the year specified.

"\# of Paragraphs" is the number of paragraphs containing references to ICT for the year specified. Each point is recorded as a separate paragraph.

"\% of Total Paragraphs" refers to the total number of paragraphs in all documents for the year specified.

"\# of Documents" is the number of documents that contain ICT subjects and excludes dedicated documents.

"\% of Total Documents" refers to the total number of documents for the year specified.

"\# of Dedicated Documents" is the number of documents for the year that contain an ICT-related subject in the title. 


\section{Appendix I: Oxford Insights Government}

Al Readiness Ranking, 2017

\begin{tabular}{|l|l|c|c|}
\hline Rank & \multicolumn{1}{|c|}{ Country } & Score & Club \\
\hline 1 & United Kingdom & 8.4 & G7 \\
\hline 2 & United States & 8.2 & G7 \\
\hline 3 & Canada & 7.86 & G7 \\
\hline 4 & Korea & 7.81 & G20 \\
\hline 5 & Netherlands & 7.76 & EU \\
\hline 6 & France & 7.74 & G7 \\
\hline 7 & Japan & 7.59 & G7 \\
\hline 8 & Australia & 7.47 & G20 \\
\hline 9 & New Zealand & 7.37 & OECD \\
\hline 10 & Finland & 7.37 & EU \\
\hline 11 & Sweden & 7.18 & EU \\
\hline 12 & Spain & 7.17 & G7 \\
\hline 13 & Germany & 6.95 & OECD \\
\hline 14 & Israel & 6.93 & EU \\
\hline 15 & Norway & 6.91 & EU \\
\hline 16 & Austria & 6.83 & EU \\
\hline 17 & Ireland & 6.69 & G7 \\
\hline 18 & Belgium & 6.61 & OECD \\
\hline 19 & Italy & 6.58 & 6.52 \\
\hline 20 & Switzerland & & \\
\hline
\end{tabular}




\title{
Повестка дня «Группы двадцати» в области цифровизации 1
}

\author{
Дж. Киртон, Б. Уоррен
}

Киртон Джон Джеймс - профессор, содиректор Исследовательской группы БРИКС, директор Исследовательского центра «Группы восьми», содиректор Исследовательского центра «Группы двадцати», Университет Торонто; M5S 1A1, 100 St. George, Toronto, Ontario, Canada; E-mail: john.kirton@utoronto.ca

Уоррен Бриттани - руководитель мониторинга Исследовательского центра «Группы восьми» и Исследовательского центра «Группы двадцати»; 1 Devonshire Place, Room 308N, Toronto, M5S 3K7, Ontario, Canada; E-mail: b.warren@mail.utoronto.ca

В рамках данной статьи проводится системный анализ деятельности «Группы двадиати» в сфере цифровизации по основным измерениям институциональной эффективности и делаются выводы относительно причин определенных тенденций, складывающихся в этой связи [Kirton, 2013]. Авторы утверждают, что «двадиатка» постепенно повышала свою эффективность в осуществлении функций глобального управления в цифровой сфере. С самого начала деятельности института в 2008 г. повестка дня в данной области постоянно расширялась, достигнув пика в 2016-2017 гг. Лидеры «Группы двадцати» впервые обратили внимание на вопросы цифровизации вследствие глобального финансово-экономического кризиса 2008 г. На саммите в Вашингтоне была признана роль электронной торговли как важного инструмента борьбы с кризисом. Впоследствии стали обсуждаться и проблемы неравенства, лежащие в основе идеологии антиглобализма. Таким образом, был осуществлен переход от борьбы с последствиями кризиса к принятию превентивных мер. Тенденции расширения круга обсуждаемых вопросов и резкий рост их числа фиксируются по функциям определения направления действий, принятия решений и институционального развития глобального управления, однако не отражаются на функциях реализации принятых решений. Данный тренд обусловлен шокирующим ростом популистских настроений, вызванным проявлениями неравенства в Великобритании и США в 2015 и 2016 г2., а также провалом традиционных международных институтов, глобальным коллективным превосходством иленов «двадиатки» и конвергенцией их относительных возможностей в ичифровой сфере и, наконеи, консенсусом о приоритетном характере экономического роста и открытости. Важснейшим фактором, однако, стали интересы Китая, принимавшего форум в 2016 г., и Германии, председательствовавшей в 2017 г. Лидеры этих стран, заручившись политической поддержккой на национальном уровне, стремились сформировать цифровую повестку дня, обеспечиваюшую справедливое распределение благ цифровизации в противовес нарастающим популистским и протекционистским тенденциям.

Ключевые слова: цифровизация; цифровая экономика; факторы глобального управления; «Группа двадцати»; неравенство; антиглобализм; факторы эффективности

Для цитирования: Киртон Дж., Уоррен Б. (2018) Повестка дня «Группы двадцати» в области цифровизации // Вестник международных организаций. 2018. Т. 13. № 2. С. 16-41 (на русском и английском языках). DOI: 10.17323/1996-7845-2018-02-02.

\section{Источники}

Carin B. (2017) G20 Safeguards Digital Economy Vulnerabilities with a Financial Sector Focus. Economics: The Open-Access, Open Assessment E-Journal. Vol. 11. Режим доступа: http://www.economics-ejournal. org/economics/discussionpapers/2017-27 (дата обращения: 18.04.2018).

Chetty K., Qigui L., GcoraN., Josie J., Wenwei L., Fang C. (2017) Bridging the Digital Divide: Measuring Digital Literacy. Economics Discussion Papers. No. 2017-69. Kiel Institute for the World Есопоту. Режим доступа: http://www.economics-ejournal.org/economics/discussionpapers/2017-69 (дата обращения: 18.04.2018).

Donnan S. (2017a) US, EU and Japan to Link up on China Trade // Financial Times. 13 December. P. 2.

\footnotetext{
${ }^{1}$ Статья поступила в редакцию в декабре 2017 г.
} 
Donnan S. (2017b) WTO Wrestles with Relevance in Age of Ecommerce // Financial Times. 14 December. Режим доступа: https://www.ft.com/content/d9f63c20-e01d-11e7-a8a4-0a1e63a52f9c (дата обращения: 18.04.2018).

Gapper J. (2017) Bitcoin Casts a Shadow over Bank Payments // Financial Times. 14 December. P. 11.

G20 (2008) Declaration of the Summit on Financial Markets and the World Economy. 15 November. Режим доступа: http://www.g20.utoronto.ca/2008/2008declaration1115.html (дата обращения:18.04.2018).

G20 (2010) The G20 Toronto Summit Declaration. 27 June. Режим доступа: http://www.g20.utoronto. ca/2010/to-communique.html (дата обращения: 18.04.2018).

G20 (2015) G20 Leaders' Communiqué. 16 November. Режим доступа: http://www.g20.utoronto. ca/2015/151116-communique.html (дата обращения: 18.04.2018).

G20 (2016) G20 Blueprint on Innovative Growth. 5 November. Режим доступа: http://www.g20.utoronto. ca/2016/160905-blueprint.html (дата обрашения: 18.04.2018).

G20 (2017) Overview of Argentina's G20 Presidency in 2018. Режим доступа: https://g20.org/en/g20-argentina/priorities (дата обращения: 18.04.2018).

G20 (2017a) G20 Leaders' Declaration: Shaping an Interconnected World. Режим доступа: http://www.g20. utoronto.ca/2017/2017-G20-leaders-declaration.html (дата обращения: 18.04.2018).

Global Wealth Report (2017) Global Wealth Report 2017. Credit Suisse Research Institute. Режим доступа: https://www.credit-suisse.com/corporate/en/research/research-institute/global-wealth-report.html (дата обращения: 18.04.2018).

ILO (nd) Global Commission on the Future of Work. Режим доступа: http://www.ilo.org/global/topics/ future-of-work/WCMS_569528/lang--en/index.htm (дата обращения: 18.04.2018).

ITU, UNESCO (2017) The State of Broadband: Broadband Catalyzing Sustainable Development. Broadband Commission for Sustainable Development, ITU and UNESCO. September. Режим доступа: https://www. itu.int/dms_pub/itu-s/opb/pol/S-POL-BROADBAND.18-2017-PDF-E.pdf (дата обращения: 18.04.2018).

Kirton J. (2013) G20 Governance for a Globalized World. Farnham: Ashgate.

Kirton J. (2016) China's G20 Leadership. Farnham: Ashgate.

Kirton J. (2017) A Summit of Solid Success at Hamburg in 2017. G20 Research Group. 8 July. Режим доступа: http://www.g20.utoronto.ca/analysis/170708-kirton-success.html (дата обращения: 18.04.2018).

Kirton J., Warren B. (2017) G20 Insights: T20 Recommendations Realized. G20 Research Group. 3 November. Режим доступа: http://www.g20.utoronto.ca/analysis/t20-2017-recommendations-realized.html (дата обрашения: 18.04.2018).

Mariani S., Dionne M. (2017) "How Can the G20 Use AI to Help Create Sustainable Communities in an InterConnected World?” G20 Information Centre. 21 September. Режим доступа: http://www.g7g20.utoronto.ca/ comment/170921-mariani-dionne.html (дата обращения: 18.04.2018).

Maupin J. (2017) The G20 Countries Should Engage with Blockchain Technologies to Build an Inclusive, Transparent, and Accountable Digital Economy for All. Economic Discussions Papers. No. 2017-48. Kiel Institute for the World Economy.

Manyika J., Chui M., Miremadi M., Bughin J., George K., Wilmott P., Dewhurst M. (2017) A Future That Works: Automation, Employment, and Productivity. McKinsey Global Institute January.

OECD (2014) Measuring the Digital Economy: A New Perspective. Режим доступа: http://dx.doi. org/10.1787/9789264221796-en (дата обращения: 18.04.2018).

OECD (2016) Automation and Independent Work in a Digital Economy. Policy Brief on the Future of Work, Мау. Режим доступа: https://www.oecd.org/els/emp/Policy\%20brief\%20-\%20Automation\%20and\%20Independent\%20Work\%20in\%20a\%20Digital\%20Economy.pdf (дата обращения: 18.04.2018).

OECD (2016a) Ministerial Declaration on the Digital Economy. OECD 2016 Ministerial Meeting, The Digital Economy: Innovation, Growth and Social Prosperity, 21-23 June. Режим доступа: https://www.oecd.org/ internet/Digital-Economy-Ministerial-Declaration-2016.pdf (дата обращения: 18.04.2018). 
OECD (2017) Key Issues for Digital Transformation in the G20. Report Prepared for a Joint G20 German Presidency / OECD Conference. Berlin, Germany. 12 January. Режим доступа: https://www.oecd.org/g20/ key-issues-for-digital-transformation-in-the-g20.pdf (дата обращения: 18.04.2018).

OECD (2017a) OECD Digital Economy Outlook 2017. Режим доступа: http://dx.doi.org/10.1787/978926 4276284-en (дата обращения: 18.04.2018).

Patel P. (2017) Will Automation Kill or Create Jobs? The Institute. 7 March. Режим доступа: http://theinstitute.ieee.org/ieee-roundup/blogs/blog/will-automation-kill-or-create-jobs (дата обращения: 18.04.2018).

Rosenbaum M. (2017) Local Voting Figures Shed New Light on EU Referendum. 6 February. Режим доступа: http://www.bbc.com/news/uk-politics-38762034 (дата обращения: 18.04.2018).

Rothwell J.T., Diego-Rosell P. (2016) Explaining Nationalist Political Views: The Case of Donald Trump. Gallup: George Washington University Institute of Public Policy. 2 November. Режим доступа: https://papers. ssrn.com/sol3/papers.cfm?abstract_id=2822059 (дата обращения:18.04.2018).

Snower D. (2017) The G20 Summit was More Successful than You Think. G20 Insights. Режим доступа: http://www.g20-insights.org/2017/07/11/g20-summit-successful-think/ (дата обращения: 18.04.2018).

Stirling R., Miller H., Truswell E.M. (2017) Government AI Readinness Index. Oxford Insights.

Tyson A., Maniam S. (2016) Behind Trump's Victory: Divisions by Race, Gender, Education. Pew Research Centre. 9 November. Режим доступа: http://www.pewresearch.org/fact-tank/2016/11/09/behind-trumpsvictory-divisions-by-race-gender-education/ (дата обращения: 18.04.2018).

WEF (2017) Global Risks Report 2017. Режим доступа: http://reports.weforum.org/global-risks-2017/ (дата обращения: 18.04.2018). 